\title{
Correlation of Ultrastructural Changes of Endothelial Cells and Astrocytes Occurring during Blood Brain Barrier Damage after Traumatic Brain Injury with Biochemical Markers of Blood Brain Barrier Leakage and Inflammatory Response
}

\author{
D. VAJTR ${ }^{1,3}$, O. BENADA ${ }^{2}$, J. KUKAČKA $^{1}$, R. PRŮŠA $^{1}$, L. HOUŠŤAVA $^{4}$, P. TOUPALÍK $^{5}$, \\ R. KIZEK ${ }^{6}$
}

${ }^{1}$ Department of Clinical Biochemistry and Pathobiochemistry, Charles University $2^{\text {nd }}$ Faculty of Medicine and University Hospital Motol, Prague, ${ }^{2}$ Institute of Microbiology, v.v.i. Academy of Sciences of the Czech Republic, Prague, ${ }^{3}$ Department of Forensic Medicine and Toxicology, Charles University $1{ }^{\text {st }}$ Faculty of Medicine, Prague, ${ }^{4}$ Neurosurgery Department, Charles University $3^{\text {rd }}$ Faculty of Medicine, Prague, ${ }^{5}$ Department of Forensic Medicine, Charles University $2{ }^{\text {nd }}$ Faculty of Medicine, Prague, ${ }^{6}$ Department of Chemistry and Biochemistry, Mendel University of Agriculture and Forestry, Brno, Czech Republic

Received March 28, 2007

Accepted December 4, 2007

On-line April 1, 2008

\section{Summary}

Focal cerebral contusion can be dynamic and expansive. It has been proved that subsequent expansive contusion is caused by brain parenchyma damage, especially BBB damage. We investigated a group of patients with traumatic brain injury. The patients $(n=18)$ were divided into group I $(n=7)$ of patients submitted to neurosurgery due to expansive contusion, and group II $(n=11)$ of patients without surgery. Serum concentrations of NSE and S-100B protein were measured by electrochemiluminescence immunoassay, interleukin-6 (IL-6) was measured by chemiluminescent sequential immunometric assay and matrix metalloproteinases (MMP-9, MMP-2) were measured by immunoassays. Cortical biopsy specimens of brain were investigated by electron microscopy in patients with trauma brain injury submitted to neurosurgery. Biochemical investigation from first day up to third day after traumatic brain injury proved increased values of IL-6 (302.2 \pm 119.9 vs. $59.6 \pm 11.9 \mathrm{ng} / \mathrm{l}$, $\mathrm{p}<0.02)$ and S-100B protein $(3.064 \pm 1.064$ vs. $0.649 \pm 0.182 \mu \mathrm{g} / \mathrm{l}$, $\mathrm{p}<0.05$ ) in patients with expansive lesion compared to patients without expansive contusion. Significantly higher levels of MMP-9 $(150.4 \pm 28.46$ vs. $74.11 \pm 13.16 \mathrm{ng} / \mathrm{l}, \mathrm{p}<0.05)$ and of MMP-2 ( $814.5 \pm 126.3$ vs. $523.1 \pm 25.28 \mathrm{ng} / \mathrm{l}, \mathrm{p}<0.05)$ were found during first 3 days after admission in group I compared to group II. MMP-9 has also elevated in group II from lower values after admission $(74.11 \pm 13.16 \mathrm{ng} / \mathrm{l})$ up to high levels on the 10th day of hospitalization $(225.1 \pm 49.35 \mathrm{ng} / \mathrm{l})$. Ultrastructural investigation of endothelial cells and surrounded tissue revealed perivascular hemorrhage, increased pinocytic activity of endothelial cells, and
\end{abstract}

cytotoxic edema of astroglial cells. Multivesical bodies were disclosed inside the endothelial cells. Higher levels of serum protein S-100B and IL-6 correlated with ultrastructural changes of endothelial cells, and with inflammatory response following TBI, respectively.

\section{Key words}

Blood brain barrier • Expansive contusion - Metalloproteinases • S-100B protein $\bullet$ Interleukin-6

\section{Corresponding author}

D. Vajtr, Department of Clinical Biochemistry and Pathobiochemistry, Charles University $2^{\text {nd }}$ Faculty of Medicine and University Hospital Motol, V Úvalu 84, 15006 Praha 5, Czech Republic. E-mail: vajtr.david.1LFUK@seznam.cz

\section{Introduction}

Traumatic brain injury (TBI) is one of the major causes of morbidity and mortality. Outcome for braininjured patients is determined by the type, severity, and location of the injury. Focal brain injuries comprising such as contusions, and diffuse injuries differ fundamentally (Graham et al. 1988). Focal cerebral contusion can be dynamic and expansive. Increasing intracranial pressure 
subsequent to uncontrollable swelling is the most frequent cause of death in TBI patients (Ragaisis 2002). It has been proved that subsequent expansive contusion is caused by brain parenchyma damage, especially the blood-brain barrier (BBB) damage (Baldwin et al. 1996, Adelson et al. 1998). Poor clinical management can bring the increase of hypoperfusional (pericontusional) zone and leads to expansion of contusion into normal brain. BBB failure occurring in traumatic brain injury is caused in part by activation of the proinflammatory factors (Holmin et al. 1995, 1998) and matrix metalloproteinases (such as MMP9). BBB protective cascades have recently been described, including NO-mediated interleukin-6 (IL-6) released by glia. Interleukin- 6 has been shown to trigger production of matrix metalloproteinase inhibitors (Cucullo et al. 2003). Other markers, such as NSE and S-100B, released from damaged tissue have been used to monitor the extent of traumatic brain injury (Woertgen et al. 1997, 1999, 2002, Herrmann et al. 2000, Kukačka et al. 2006, Naeimi et al. 2006, Sawauchi et al. 2005). As specific marker of bloodbrain barrier leakage rather than of neuronal damage was hypothesized S-100B protein. Experimental data with patients undergoing iatrogenic $\mathrm{BBB}$ disruption with mannitol suggests that $\mathrm{S}-100 \mathrm{~B}$ was an early marker of BBB opening (Kapural et al. 2002). Ultrastructural investigation of expansive contusions reveals perivascular hemorrhage (Schalen et al. 1991), astrocytic swelling (Castejon 1998), changes in the myelin, lysosome abnormalities and lipofuscin content of nerve cells (Castejon 2004), infiltration of the macrophages, and apoptosis (Conti et al. 1998).

\section{Subject and Methods}

\section{Patients}

Eighteen patients with traumatic brain injury were investigated. The patients were divided into group I $(n=7)$ of patients submitted to neurosurgery, and group II of patients $(n=11)$ without surgery. All patients were examined by cranial computerized tomography (CT). All these patients were diagnosed as having suffered focal brain injury according to the CT scan performed during admission. Four patients in group II were diagnosed with signs of diffuse axonal injury (DAI) according to NMR performed 2-3 weeks after injury. The CT scan classification utilizes the degree of midline shift in millimeters and presence or absence of intra- and extracerebral hematoma according to the classification of Marshall et al. (1992). In patients submitted to neurosurgery due to expansive contusion, there were diagnosed midline shifts greater than $10 \mathrm{~mm}$ and the intracranial pressure (ICP) elevation above $10 \mathrm{~mm} \mathrm{Hg}$.

\section{Informed agreement}

The ethics committee at each institution approved this study, and written informed consent was obtained from all patients.

\section{Biochemical investigation}

Blood samples were collected during 10 days after admission. Serum NSE and S-100B protein concentrations were measured on immunoassay analyzer Roche Elecsys 2010 by electrochemiluminescence immunoassays (Roche, Switzerland). The range of NSE serum concentrations of healthy subjects is reported to be below $15.2 \mu \mathrm{g} / 1$ and for S-100B protein below $0.12 \mu \mathrm{g} / \mathrm{l}$. IL-6 was measured on analyzer Immulite 1000 by chemiluminescent sequential immunometric assay (DPC, USA) and matrix metalloproteinases (MMP-9, MMP-2) were measured by Biotrak activity assay system (GE Healthcare, USA).

\section{Electron microscopy}

Cortical biopsies of 7 patients with craniocerebral trauma submitted to surgery due to expansive lesion were processed for electron microscopy in following way: The tissue samples from pericontusional zone on the border line of necrotic contusions tissue were fixed in $3 \%$ glutaraldehyde in cacodylate buffer and postfixed with $2 \%$ osmium tetroxide. After dehydration in alcohol series, the samples were embedded into Epon resin according to the classical procedure. The stained ultrathin sections were examined in Philips CM100 electron microscope (FEI, formerly Philips EO, the Netherlands) and selected areas were digitally recorded using MegaViewII slow-scan camera. The digital images were processed in Analysis 3.2 Pro software.

\section{Statistical methods}

Differences in NSE, S-100B, MMP-9, MMP-2, and IL- 6 concentrations between groups were tested by the unpaired t-test. A $p<0.05$ was considered as statistically significant.

\section{Results}

Biochemical results

In order to analyze whether the type of brain 
Table 1. Data of either group with respect to time-profile during 10 days after admission.

\begin{tabular}{lllcccc}
\hline \multirow{1}{*}{ Markers } & $\begin{array}{l}\mathbf{1 - 3} \text { day } \\
\text { group I }\end{array}$ & $\begin{array}{l}\mathbf{1 - 3} \text { day } \\
\text { group II }\end{array}$ & $\begin{array}{c}\mathbf{4 - 6} \text { day } \\
\text { group I }\end{array}$ & $\begin{array}{c}\mathbf{4 - 6} \text { day } \\
\text { group II }\end{array}$ & $\begin{array}{c}\mathbf{7 - 1 0} \text { day } \\
\text { group I }\end{array}$ & $\begin{array}{l}\mathbf{7 - 1 0} \text { day } \\
\text { group II }\end{array}$ \\
\hline SIOOB $(\mu \mathrm{g} / \mathrm{l})$ & $3.06 \pm 1.06^{*}$ & $0.64 \pm 0.18^{*}$ & $0.71 \pm 0.29$ & $0.59 \pm 0.36$ & $0.23 \pm 0.03$ & $0.15 \pm 0.07$ \\
$N S E(\mu \mathrm{g} / \mathrm{l})$ & $42.59 \pm 7.60$ & $37.57 \pm 6.92$ & $17.94 \pm 2.89$ & $29.63 \pm 7.58$ & $27.75 \pm 0.04^{*}$ & $17.70 \pm 7.26^{*}$ \\
$M M P-9(\mathrm{ng} / \mathrm{l})$ & $150.4 \pm 28.46^{*}$ & $74.11 \pm 13.16^{*}$ & $47.69 \pm 6.46^{*}$ & $183.9 \pm 49.05^{*}$ & $52.56 \pm 14.42^{*}$ & $225.1 \pm 49.35^{*}$ \\
$I L-6(\mathrm{ng} / \mathrm{l})$ & $3022 \pm 119.9^{*}$ & $59.60 \pm 11.93^{*}$ & $408.5 \pm 280.8^{*}$ & $51.94 \pm 12.27^{*}$ & N.A. & $24.46 \pm 7.43$ \\
$M M P-2(\mathrm{ng} / \mathrm{l})$ & $814.5 \pm 126.3^{*}$ & $523.1 \pm 25.28^{*}$ & $570.8 \pm 36.33$ & $680.4 \pm 44.13$ & $514.4 \pm 18.20$ & $501.0 \pm 87.29$ \\
\hline
\end{tabular}

Asterisk indicates differences between both groups $(p<0.05)$. N.A. (not available)

contusion was associated with different release of the inflammatory and neurospecific markers, we divided patients into two groups according to the expansive behavior of contusion. We measured NSE, S-100B proteins, MMP-9, MMP-2, and IL-6 in the blood of patients submitted to neurosurgery due to expansive lesion (Group I) and in patients with contusion without expansive behavior (Group II). Table 1 shows the value of proteins in both groups with regard to time-profile after injury. A significant difference between both groups was reached within the first $72 \mathrm{~h}$.

The data indicate that all patients with contusion head injury had higher value of S-100 B and NSE serum concentration compared to the values of healthy controls (cut-off value for S-100B $0.105 \mu \mathrm{g} / 1$ and for NSE $15.5 \mu \mathrm{g} / \mathrm{l})$. With respect to all patients, the data showed a longer release of both markers (S-100B, NSE) during 10 days after injury. Value of S-100B in group I of patients with neurosurgery decreased significantly within the first 6 days. In group II we observed only a slight decrease of S-100B protein within the first 10 days. Within the first three days after traumatic brain injury, higher values of $\mathrm{S}-100 \mathrm{~B}$ protein $(3.064 \pm 1.064 \mathrm{vs}$. $0.649 \pm 0.182 \mu \mathrm{g} / \mathrm{l}, \mathrm{p}<0.05)$ were proved in group I compared to group II. No significant changes were found in levels of NSE within the first 10 days in either group.

As concerns metaloproteinases, the biochemical results confirmed significantly higher levels of MMP-9 (150.4 \pm 28.46 vs. $74.11 \pm 13.16 \mathrm{ng} / \mathrm{l}, \mathrm{p}<0.05)$, and MMP-2 $(814.5 \pm 126.3$ vs. $523.1 \pm 25.28 \mathrm{ng} / \mathrm{l}, \mathrm{p}<0.05)$ in group I compared to group II within the first $72 \mathrm{~h}$ after admission. The value of MMP-9 increased dramaticaly in patients without surgery, and value of MMP-9 ranged from $74.11 \pm 13.16 \mathrm{ng} / 1 \mathrm{up}$ to $225.1 \pm 49.35 \mathrm{ng} / 1$ during the first 10 days after admission. MMP-9 in patients undergoing neurosurgery decreased significantly within the first
6 days. We revealed no significant decrease of MMP-2 in patients submitted to neurosurgery within the first 6 days. No significant difference was found in MMP-2 values during 4-10 days in either group.

With respect to the proinflammatory factor IL-6, increased values of IL-6 (302.2 \pm 119.9 vs. $59.6 \pm 11.9 \mathrm{ng} / 1$, $\mathrm{p}<0.02$ ) were proved in both groups within the first up to third day after traumatic brain injury. Higher values of IL-6 were found in group I (408.5 \pm 280.8 vs. $51.94 \pm 12.27$ $\mathrm{ng} / \mathrm{l}, \mathrm{p}<0.05)$ compared to group II during the fourth up to sixth day. We found no significant increase of IL-6 in patients submitted to neurosurgery within the first 6 days. Value of IL-6 increased in group I and decreased in group II during 10 days after admission.

\section{Morphological results}

Ultrastructural changes of BBB were studied by electron microscopy in patients submitted to neurosurgery due to expansive contusion. In the early stages (patients submitted to neurosurgery up to $24 \mathrm{~h}$ after admission) an ultrastructural investigation of endothelial cells and surrounding tissue revealed perivascular hemorrhage. Parenchymatous hemorrhages were also observed. The extracellular space appeared considerably enlarged with the presence of proteinaceous hematogenous edema fluid and fibrinous organization. The capillary wall displayed increased vacuolar and vesicular endothelial transport (Fig. 1). Pinocytic activity of endothelial cells was increased. Longitudinal folds were found on the endothelial surfaces BBB opening was assessed by observation of extravasated proteins (fibrous matter of fibrin). Basement membrane thickening was not observed, and tight junctions were intact (Fig. 2).

Lysosome alterations and lipofuscin content of capillary endothelial cells and pericytes were proved. The lysosomes showed fragmentation of their limiting 


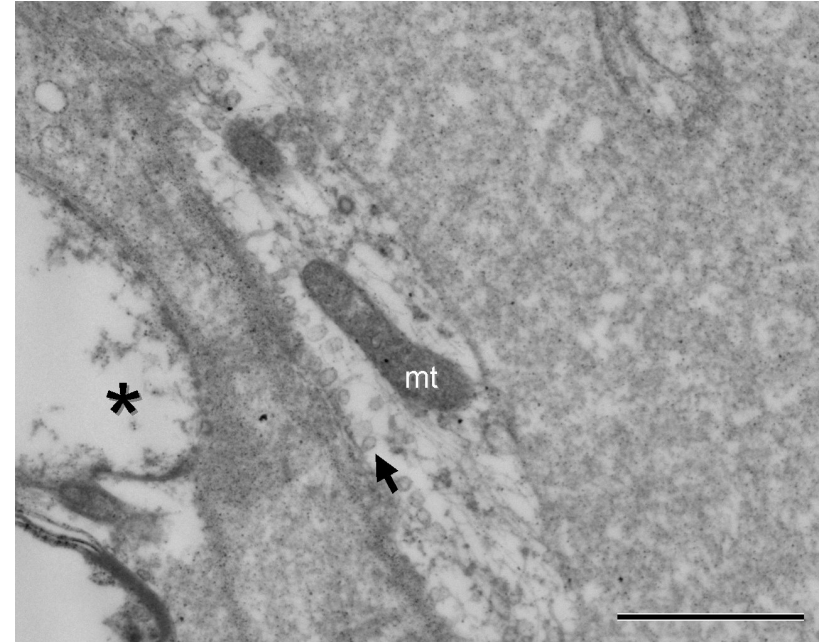

Fig. 1. Increased pinocytic activity of endothelial cells (arrow) and swelling of astrocytic perivascular processes (asterisk) were observed. $\mathrm{mt}-$ mitochondrion inside the endothelial cell. Scale bar: $1 \mu \mathrm{m}$.

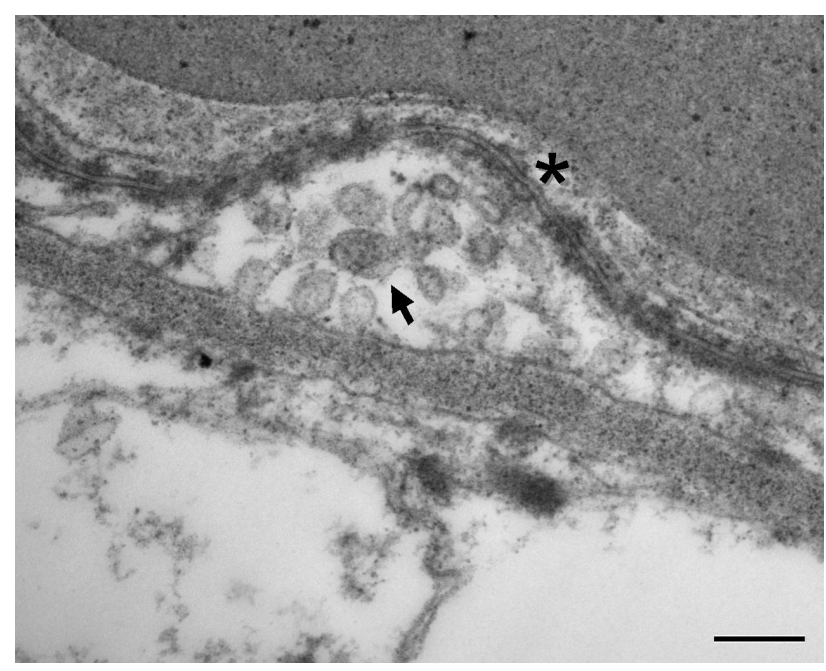

Fig. 2. Tight-junctions of endothelial cells were intact (asterisk) and early endosomal structures were formed (arrow). Scale bar: $0.2 \mu \mathrm{m}$.

membranes and an associated dense granulation. Lipofucsin granules and multivesicular bodies (Fig. 3) were also distinguished in endothelial cells and pericytes. Cytotoxic edema of astroglial cells was formed, and vacuolization and swollen astrocytic end-feet were observed (Fig. 4). The neutrophil recruitment and tethering on endothelial cells was found. The first stage of neuronophagic reaction was observed. Inflammatory response followed the ganglial cells necrosis.

\section{Discussion}

We focused on the pathological morphology of endothelial cells in BBB maintenance of its integrity. We

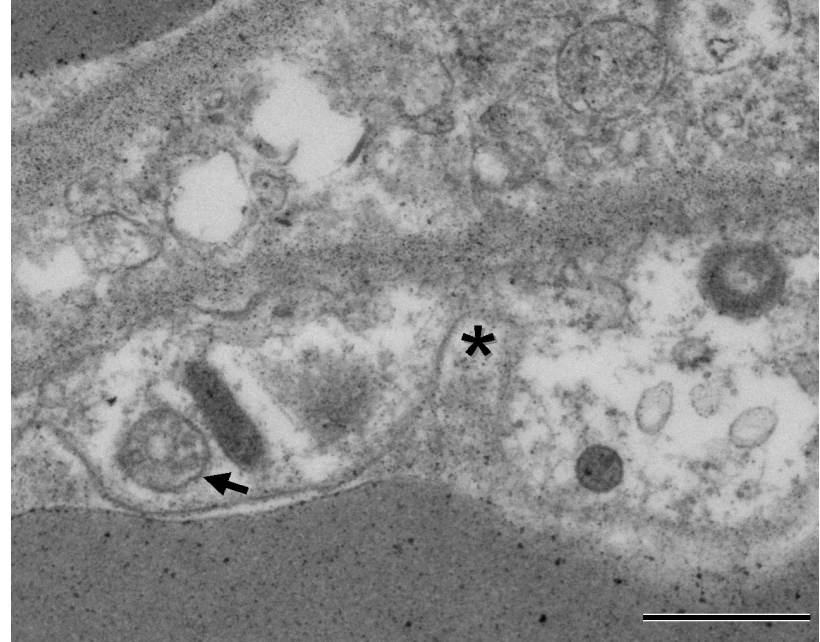

Fig. 3. Multivesical bodies were observed inside endothelial cells (arrow) and longitudinal folds and invaginations (asterisk) were found on their surface. Scale bar: $0.5 \mu \mathrm{m}$.

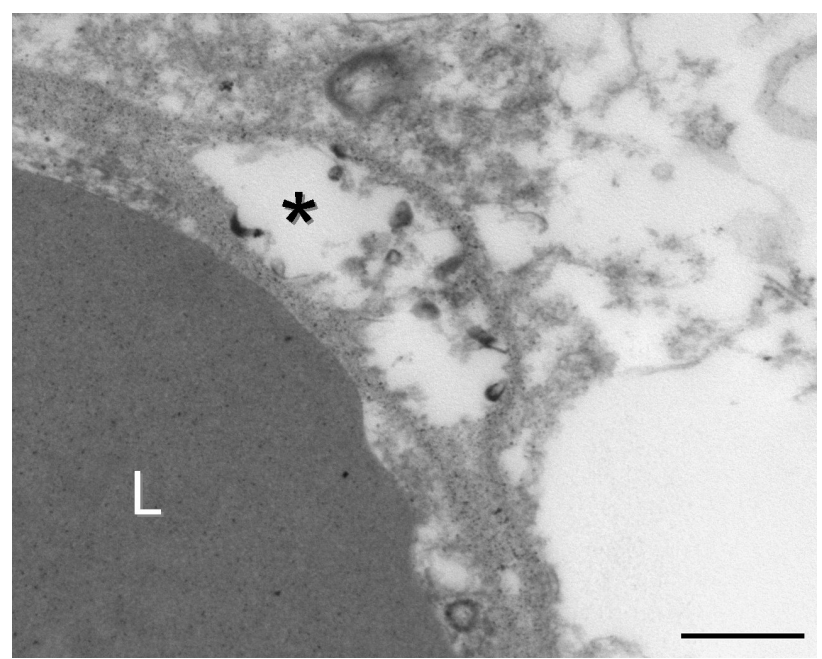

Fig. 4. Cytotoxic edema of astroglial end-feet was formed (asterisk). $\mathrm{L}$ - capillary lumen. Scale bar: $0.5 \mu \mathrm{m}$.

analyzed excised tissue obtained from those patients who underwent neurosurgery due to expansive contusion. Similar changes of ultrastructural patterns, as described here, have also been reported by Castejon (1998, 2004). The role of pericytes in maintenance of $\mathrm{BBB}$ is still unclear in details. BBB failure may also be monitored by measuring proteins S-100B and IL-6 released from perivascular astrocytes. According to the hypothesis of Kapural et al. (2002) S-100B protein should be a specific marker of BBB leakage. In our study we confirmed that higher levels of serum protein S-100B correlated with the changes in ultrastructure of blood brain barrier (endothelial cells and astrocytes) in expansive contusions. According to Holmin et al. (1995, 1998) BBB failure is partly caused by activation of proinflammatory factors. This activation may contribute to the progression of tissue 
damage and matrix destruction leading to $\mathrm{BBB}$ failure after a traumatic brain injury. We confirmed that the patients with expansive contusion had higher level of IL-6 (1-3 days mean value $302.2 \mathrm{ng} / \mathrm{l}$, and 4-6 days mean value $408.5 \mathrm{ng} / \mathrm{l})$ than the patients without neurosurgery. These data monitoring the increase of IL- 6 during the first up to third day after admission correlated with the conclusion of Holmin and Hojeberg (2004) proving strong expression of pro-inflammatory cytokine interleukin (IL)-1-beta, and IL-6 in patients undergoing surgery less than $24 \mathrm{~h}$ after the trauma. In the central nervous system, matrix remodeling by MMPs plays a major role in maintaining $\mathrm{BBB}$ integrity. The values of MMP-9 were elevated in group of the patients without neurosurgery and ranged from $74.11 \pm 13.16 \mathrm{ng} / \mathrm{l}$ up to $225.1 \pm 49.35 \mathrm{ng} / \mathrm{l}$ during 10 days of hospitalization. However, none of the signs of clinical response on BBB damage preceded by elevation of MMP-9 were proved on the CT scans. Our study documented that the higher value of IL-6 corresponded with inflammatory response after TBI, and higher value of S-100B protein correlated with changes in ultrastructure of astroglial end-feet. In patients without neurosurgery the values of MMPs were higher for 4-10 days. These findings might reflect the importance of surgery. The secondary TBI may impair the outcome of patient. We have demonstrated that the decrease of MMP-9 and MMP-2 in group I can prevent triggering of secondary TBI, especially the BBB leakage. Increased value of IL-6 confirmed this hypothesis with respect to the reports that IL-6 plays the role of $\mathrm{BBB}$ protective factor. Removing damaged tissue may prevent the increase of molecular cascades triggered by secondary TBI.

\section{Conclusions}

We confirmed that the brain barrier dysfunction might represent the morphological substrate correlating with higher levels of serum protein S-100B, and inflammatory response following TBI leads to higher values of IL-6. We have proved that neurosurgery was connected with a decrease of MMP-9 or MMP-2 and an increase of IL-6 compared to inverse development of value in the group without surgery.

\section{Conflict of Interest}

There is no conflict of interest.

\section{Acknowledgements}

We thank M. Elleder for expert assistance. Our work was supported by IGA CR, reg. no. NR/8793-3/2006 and Institutional Scientific Project AV0Z50200510.

\footnotetext{
Abbreviations

BBB - blood brain barrier, TBI - traumatic brain injury, CT - computerized tomography, DAI - diffuse axonal injury, MMPs - metalloproteinases, IL-6 - interleukin 6, NSE - neuron specific enolase, S-100 B - calcium binding protein, EC - endothelial cells, ICP - intracranial pressure.
}

\section{References}

ADELSON PD, WHALEN MJ, KOCHANEK PM, ROBICHAUD P, CARLOS TM: Blood brain barrier permeability and acute inflammation in two models of traumatic brain injury in the immature rat: a preliminary report. Acta Neurochir Suppl 71: 104-106, 1998.

BALDWIN SA, FUGACCIA I, BROWN DR, BROWN LV, SCHEFF SW: Blood-brain barrier breach following cortical contusion in the rat. J Neurosurg 85: 476-481, 1996.

CASTEJON OJ: Electron microscopic analysis of cortical biopsies in patients with traumatic brain injuries and dysfunction of neurobehavioural system. J Submicrosc Cytol Pathol 30: 145-156, 1998.

CASTEJON OJ: Lysosome abnormalities and lipofucsin content of nerve cells of oedematous human cerebral cortex. J Submicrosc Cytol Pathol 36: 263-271, 2004.

CONTI AC, RAGHUPATHI R, TROJANOWSKI JQ, MCINTOSH TK: Experimental brain injury induces regionally distinct apoptosis during the acute and delayed post-traumatic period. J Neurosci 18: 5663-5672, 1998.

CUCULLO L, MARCHI N, MARRONI M, FAZIO V, NAMURA S, JANIGRO D: Blood-brain barrier damage induces release of alpha2-macroglobulin. Mol Cell Proteomics 2: 234-241, 2003.

GRAHAM DI, ADAMS JH, GENNARELLI TA: Mechanisms of non-penetrating head injury. Prog Clin Biol Res 264: 159-168, 1988. 
HERRMANN M, JOST S, KUTZ S, EBERT AD, KRATZ T, WUNDERLICH MT, SYNOWITZ H: Temporal profile of release of neurobiochemical markers of brain damage after traumatic brain injury is associated with intracranial pathology as demonstrated in cranial computerized tomography. J Neurotrauma 17: 113-122, 2000.

HOLMIN S, HOJEBERG B: In situ detection of intracerebral cytokine expression after human brain contusion. Neurosci Lett 369: 108-114, 2004.

HOLMIN S, MATHIESEN T, SHETYE J, BIBERFELD P: Intracerebral inflammatory response to experimental brain contusion. Acta Neurochir (Wien) 132: 110-119, 1995.

HOLMIN S, SODERLUND J, BIBERFELD P, MATHIESEN T: Intracerebral inflammation after human brain contusion. Neurosurgery 42: 291-298, 1998.

KAPURAL M, KRIZANAC-BENGEZ L, BARNETT G, PERL J, MASARYK T, APOLLO D, RASMUSSEN P, MAYBERG MR, JANIGRO D: Serum S-100beta as a possible marker of blood-brain barrier disruption. Brain Res 940: 102-104, 2002.

KUKAČKA J, VAJTR D, HUSKA D, PRŮŠA R, HOUŠŤAVA L, ŠAMAL F, DIOPAN V, KOTAŠKA K, KIZEK R: Blood metallothionein, neuron specific enolase, and protein $\mathrm{S} 100 \mathrm{~B}$ in patients with traumatic brain injury. Neuro Endocrinol Lett 27 (Suppl 2): 116-120, 2006.

NAEIMI ZS, WEINHOFER A, SARAHRUDI K, HEINZ T, VÉCSEI V: Predictive value of S-100B protein and neuron specific-enolase as markers of traumatic brain damage in clinical use. Brain Inj 20: 463-468, 2006.

MARSHALL LF, MARSHALL SB, KLAUBER MR, VAN BERKUM CLARK M, EISENBERG H, JANE JA, LUERSSEN TG, MARMAROU A, FOULKES MA: The diagnosis of head injury requires a classification based on computed axial tomography. J Neurotrauma 9 (Suppl 1): S287-S292, 1992.

RAGAISIS V: Brain contusion: morphology, pathogenesis and treatment. Medicina (Kaunas) 38: 243-249, 2002.

SAWAUCHI S, TAYA K, MURAKAMI S, ISHI T, OHTSUKA T, KATO N, KAKU S, TANAKA T, MOROOKA S, YUHKI K, URASHIMA M, ABE T: Serum S-100B protein and neuron-specific enolase after traumatic brain injury. No Shinkei Geka 33: 1073-1080, 2005.

SCHALEN W, MESSETER K, NORDSTROM CH: Cerebral vasoreactivity and the prediction of outcome in severe traumatic brain lesions. Acta Anaesthesiol Scand 35: 113-122, 1991.

WOERTGEN C, ROTHOERL RD, HOLZSCHUH M, METZ C, BRAWANSKI A: Comparison of serial S-100 and NSE serum measurements after severe head injury. Acta Neurochir 139: 1161-1164, 1997.

WOERTGEN C, ROTHOERL RD, METZ C, BRAWANSKI A: Comparison of clinical, radiologic, and serum marker as prognostic factors after severe head injury. J Trauma 47: 1126-1130, 1999.

WOERTGEN C, ROTHOERL RD, BRAWANSKI A: Early S-100B serum level correlates to quality of life in patients after severe head injury. Brain Inj 16: 807-816, 2002. 